\title{
PROMOTING A MOTIVATIONAL WORKFORCE IN NURSING PRACTICE
}

\author{
Karien Jooste \\ D Litt et Phil (UNISA) \\ Professor, Department of Nursing Science, Rand Afrikaans University, South Africa \\ Correspondence: kjo@edcur.rau.ac.za
}

Keywords: motivation; self-esteem; self-concept; interpersonal skills; direct supervision

\begin{abstract}
The motivation of nurses is a crucial contributing factor to effective health care organisations in South Africa. Major changes are taking place due to the transformation of health services and the migration of nurses in this field. Within this changing environment, nurses might find themselves unfamiliar with their surroundings. This could lead to a lack of involvement and a lack of motivation to participate in the delivery of quality health care. As it was unclear to the author as to what the opinions of nurses were regarding their role, and those of nurse managers in addressing nurses' motivational needs in the work situation, this study on motivation was conducted. This study aimed at highlighting the role of the nurse supervisor's and the nurse's role in establishing a motivated nursing corps. An explorative, descriptive, quantitative research project was embarked upon. A purposive, convenience and voluntary sample of 112 nurses attending a second year university course in Health Services Management, was selected to participate in this study. The findings indicate the motivational needs important to nurses. Guidelines were formulated according to which these motivational needs of nurses could be satisfied in future. The purpose of this article is to sensitise nurses and supervisors at all levels of the hierarchy to become more aware of their role in motivating themselves and others in their working environment.
\end{abstract}

\section{OPSOMMING}

Die motivering van verpleegkundiges is 'n kritiese aangeleentheid wat as bydraend tot effektiewe gesondheidsorgorganisasies in Suid-Afrika gesien kan word. Groot veranderinge is besig om plaas te vind weens transformasie van gesondheidsdienste en die migrasie van verpleegkundiges in hierdie veld. Hierdie veranderende omgewing kan daartoe aanleiding gee dat verpleegkundiges, wat nie meer met hul werksomstandighede vertroud is nie, 'n gebrek aan deelname en 'n gebrek aan motivering kan openbaar om gehaltesorg aan die gemeenskap te lewer. Aangesien dit nie vir die outeur duidelik was watter menings verpleegkundiges huldig aangaande die rol van die verpleegbestuurder en hulle eie rol in die aanspreek van hulle motiveringsbehoeftes in die werksituasie nie, was hierdie studie oor motivering onderneem. Die doel van hierdie studie was om die rol van die verpleegbestuurder en die verpleegkundige se eie rol te beklemtoon in die vasstelling van 'n gemotiveerde verpleegkorps. 'n Verkennende, beskrywende, kwantitatiewe navorsingsprojek is onderneem. 'n Doelgerigte gerieflike en vrywillige steekproef van 112 verpleegkundiges, wat 'n universiteitskursus in die tweede jaar in Gesondheidsdiensbestuur bygewoon het, was geselekteer om in hierdie studie deel te neem. Die bevindinge dui die belangrike motiveringsbehoeftes van verpleegkundiges aan. Riglyne is geformuleer waarvolgens hierdie motiveringsbehoeftes van verpleegkundiges in die toekoms vervul kan word. Die doel van hierdie artikel is om verpleegkundiges en toesighouers op alle vlakke van die hiërargie te sensibiliseer om meer bewus te word van hul rol in die motivering van hulself en ander in hul werksomgewing. 


\section{INTRODUCTION AND GENERAL BACK- GROUND}

"Motivation is the forces, either internal or external to a person, that arouse enthusiasm and persistence to pursue a certain course of action" (Daft, 1999:238). In recent years, the importance of these "forces" has been given substantial managerial support. Studies have shown that forces such as commitment and morale of staff have altered following the introduction of a raft of techniques under the motivation and empowerment banner (Cunningham \& Hyman, 1996:14). In general motivation of employees is an essential part of the effective functioning of an organisation in its quest to meet its objectives.

The motivation of nurses has high value for the nursing profession and other health professions. Nurses who are motivated tend to put forward their creative ideas, accept delegated responsibilities, promote open discussions with colleagues and supervisors and tend to be receptive for new ideas. The result is that these nurses become active participants in planning the future of a service.

Although much has been written about the roles, functions and skills the nurse and the nurse manager regarding motivation, the continuously changing organisational context necessitates consistent new perspectives and ways in which to motivate members of staff. It is important to continuously identify sets of skills, which would urge supervisors and nurses to contribute towards achieving the strategic goals of the health care organisation.

Towards this end, the present article reflects upon some of the motivational needs of nurses and strategies to meet these needs. Nurse managers should be cognisant of these needs and alleviating strategies to enhance motivation within themselves and within subordinates in the work environment.

\section{LITERATURE REVIEW}

Managers should create a motivational environment in which nurses are empowered and in which work satisfaction are promoted. The role of the nurse manager in motivating employees entails more than merely acting as a role model. It includes being available during work performances as a guide, to advise and to direct subordinates (Vogt \& Murrell, 1990:34). Effective supervisors and managers inspire others with the enthusiasm they gain from their vision and the pride they take in their work accomplishments. Pride, as an intrinsic motivational force, allays the need for extrinsic incentives such as remuneration. Hereby, the individual's locus of control also becomes internal as opposed to an unsatisfying and very demanding external locus of control. This in turn enhances the individual's self-concept, which paves the way for the individual to become a true expert in what he or she does. Expertise again leads to the assignment of more tasks to the individual that are more complex and which are accompanied by more responsibility (Kramer \& Schmalenberg, 1993:64). This motivates individuals towards continuous outstanding performances. It is therefore apparent that the individual nurse should be personally involved in the accomplishment of personal objectives. Involvement and intrinsic motivation and locus of control in this instance go hand-in-hand.

Individual nurses should be informed continually about their work performances, and suggestions for improvement thereof should be given by the manager (Mdongo, 1995:16). Feedback as an instrument in enhancing motivation leads individuals and teams to change their attitudes and performances positively (Kinlaw, 1996:106). However, oral feedback should be specific and employees should be encouraged by the supervisor to believe in themselves to be successful (Kramer \& Schmalenberg, 1993:64). Positive feedback from managers plays an all-important role in reassuring staff and in creating staff satisfaction and personal growth.

Nurses should have an inherent pride regarding their expertise and their contributions to nursing practice. Acknowledgement programmes could promote the quality of the performance of duties of nurses. Selection and promotion systems are required to identify and acknowledge outstanding nurses (Byham, 1992:11). These are not only a positive step in the direction of motivation, but also leads to self-affirmation, self-regulation and an inherent quality control that gives rise to a continuous rendering of quality services.

The expansion and the enrichment of the scope, complexity and responsibility of tasks assigned to nurses are also important in establishing a motivational mi 
lieu. The self-esteem of nurses increases when they are allowed to become more autonomous in decisionmaking during the performance of their assigned tasks. Allowing nurses to choose the area of interest and preference in which their expertise will be utilised can also enhance motivation. The opportunity to acquire more skills and to apply them in new situations is especially rewarding to nurses and thus also serves as an important motivational force.

A graphic representation of the results of the broader literature overview of this study is given in Figure 1. This representation served the purpose of a summative conceptual framework for the development of a research instrument in terms of which the findings were interpreted.

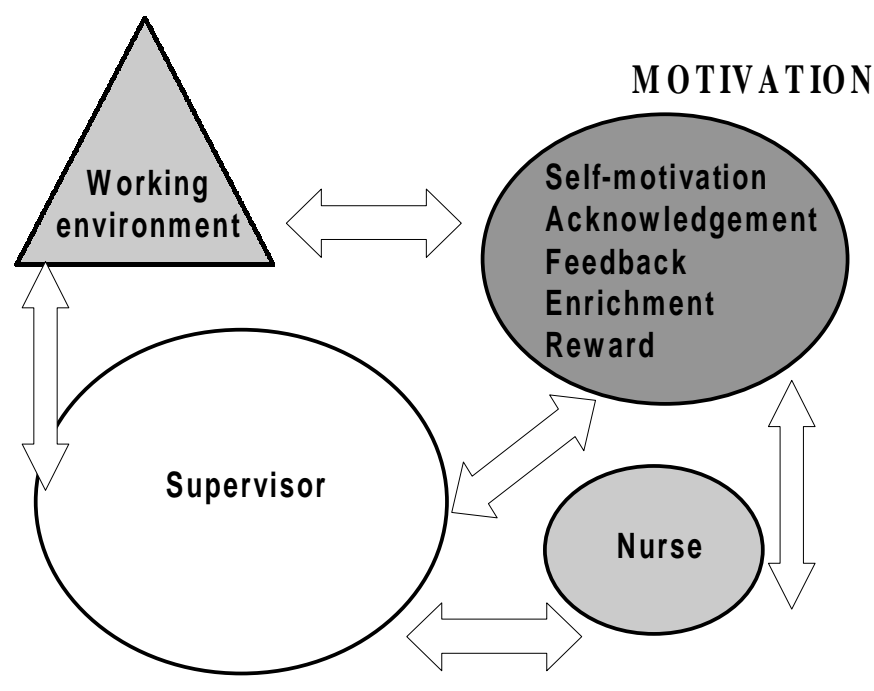

Figure 1: Conceptual framework

\section{KEY CONCEPTS}

The graphic representation contained in Figure 1 defines a number of concepts pertinent to the present study.

The working environment refers to a health care setting, in the public or private setting, in which nursing care is provided to patients.

The nurse supervisor represents a nurse manager who, due to her hierarchical position, plays a leading role in motivating subordinate nurses via different motivational strategies.

The nurse is an individual caregiver with special motivational needs in the working environment. She is capable of self-motivation and of motivating others.

\section{PROBLEM STATEMENT, PURPOSE, OB- JECTIVES AND RESEARCH QUESTIONS}

While a great deal of understanding has been gained about the motivation of health care professionals in European countries (Analoui, 2000:324), very little has been done in South Africa in this regard. With reference to the present study, the researcher (author) questioned the way in which nurses in the Gauteng region of South Africa, attending a course in Health Services Management at a distance education institution, viewed their motivational needs in the working situation. More specifically, the problem focussed on the role of the direct supervisor's role, and the subordinate nurse's role, establishing and maintaining a motivated nursing corps in the health care arena. This study thus aimed at identifying the motivational needs of nurses with the purpose of developing guidelines/strategies needed, to satisfy these motivational needs.

These were attained by answering the following research questions via the chosen research design:

- How does the direct nurse supervisor contribute to the motivation of her subordinates?

- Which elements of the self-concept of nurses (subordinates and supervisors) contribute to motivation in the workplace?

- What is the nurse as subordinate's role in enhancing her own motivation in the workplace?

\section{SIGNIFICANCE OF THE STUDY}

The provision of quality care in an ever-changing health care environment is a challenge for nurses that can only be achieved by motivated and empowered nurses. The importance and significance of the present study therefore reside in its attempt to throw light on the motivational needs of a section of the South African nursing corps, and to formulate strategic guidelines to enhance motivation within the nursing corps. Notwithstanding the fact that motivation is a highly intrinsic and personal phenomenon, nurse managers can assist subordinates in enhancing their motivation. The results of the present research assist the nurse managers in a specific area in the South African nursing corpse in understanding what the most important motivational needs of these nurses are, and what actions should be taken to motivate nurses effectively in their working environment. 


\section{RESEARCH DESIGN}

To find appropriate answers to the research questions, a quantitative, descriptive, explorative study was deemed the most appropriate research design. By utilising the quantitative paradigm an emphasis is placed on the quantification of constructs and description of human behaviour (Babbie \& Mouton, 2001:49). The purpose of exploratory research is to gain insight into a situation, phenomenon, community or person (Bless \& Higson-Smith, 1995:42-44). The descriptive element of the present study resides mostly in the utilisation of descriptive statistics and the restriction placed on the utilisation of inferential statistics due to the population specificity of the sample and the limitations imposed by the sampling method and strategy in relation to the broader universe of nurses in South Africa.

The research group (population) consisted of 320 nursing students on the functional, middle and top levels of management, working in the public and private health services in Gauteng and registered for a course in Health Sciences management at a local tertiary distance education institution. A purposive and convenience sample was extracted from these students attending compulsory laboratory workshops. The sample consisted of 112 volunteer participants.

For the purpose of this study the participants are referred to as lower and higher levels of nurses as indicated in Figure 2. The term "lower level nurses" refers to the senior professionals nurses (38\%) and professional nurses $(32 \%)$. On the other hand, higher-level nurses are represented by nursing service managers $(10 \%)$ and chief professionals nurses (20\%). Different spheres in nursing, including teaching, hospital wards, urban and rural clinics, hospital administration sections, casualty services, poli-clinics, intensive/high care, and the participants representing operating theatre.
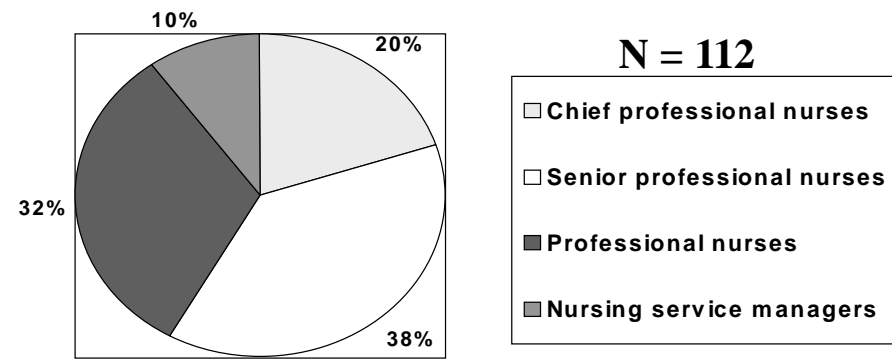

Figure 2: Respondents' position within the service
A questionnaire was developed to gather data, which would answer the research questions and attain the stated aim and objectives. Items contained in the questionnaire were based on the result of the literature review and the diagrammatic representation thereof as portrayed in Figure 1. The questionnaire was designed in such a manner that respondents merely needed to tick their responses from a series of alternatives to the 120 items contained in the questionnaire.

\section{RELIABILITY AND VALIDITY}

Reliability is a matter of whether a particular technique, applied repeatedly to the same object, would yield the same result each time (Babbie \& Mouton, 2001:119). It was ensured by having had the instrument critically evaluated by ten expert nurse managers as well as by a statistician to rule out misinterpretation of questions by revising ambiguously and inaccurately stated items and alternative responses. The success of this venture is reflected by the result of an item analysis done on the research data, which obtained a Cronbach alpha $(\alpha)$ of 0,839 , a reading indicative of a reasonably reliable instrument (Guy, Edgly, Arafat \& Allen, 1987: 171; Mulder, 1989:217).

Validity refers to the extent to which an empirical measure adequately reflects the concept's meaning (Babbie \& Mouton, 2001:122). Face and content validity were ascertained through experts in the field of Health Services Management who critically reviewed the questionnaire. Suggested improvements were implemented. Content validity was further ascertained by relating all items to the graphic representation and by having accommodated al concepts portrayed in this representation (Figure 1) in the questionnaire.

\section{DATA ANALYSIS}

Descriptive statistics were used to analyse, synthesise and describe data as indicated by Polit \& Hungler (1993:272). Important issues emerged as the data were subjected to the chi-square test $\left(\mathrm{X}^{2}\right)$ for significance in differences. This test indicates significant differences in agreements and disagreements (response frequency) to items made by participants. It thus discriminates between the response frequencies of higher and lower level nurses. 


\section{ETHICAL CONSIDERATIONS}

As participation in the research was voluntary, students were given the assurance that whether or not they participated in the study, no harm would come to them and that they would not be victimised. Participants were ensured of both anonymity and confidentiality. Anonymity was established by having had questionnaires completed incognito. The names of respondents did not appear on the questionnaires and the case numbers assigned to questionnaires were not in any way related to the identity of individual participants. Confidentiality was attained via anonymity and by not having divulged any information about the study and data to outsiders. Participants were informed of the importance and benefits of undertaking the research study and of access to the results of the study at completion.

Research ethics were also adhered to by not having manipulated data outside of the structure and process of the appropriate statistical calculations. In addition, acknowledgement was given in the form of complete references to sources from which information was obtained.

\section{FINDINGS}

The findings are presented according to the research questions formulated to attain the objectives of this study.

\section{The role of the direct supervisor in moti- vating subordinate nurses}

In this section of the presentation of data, only the significant agreements and differences found in the data are discussed.

The majority of respondents (frequencies $90 \%$ and more) were significantly in agreement that specific interpersonal skills of the supervisor could contribute towards the motivation of subordinates. The managerial skills of a supervisor that were identified by respondents as important in motivating staff were the following: clear presentations of e.g. presenting new information, negotiating skills, showing empathy, assertive problem-solving strategies and acceptance of criticism. These are exhibited in Figure 3 and are entitled Interpersonal skills of the manager.

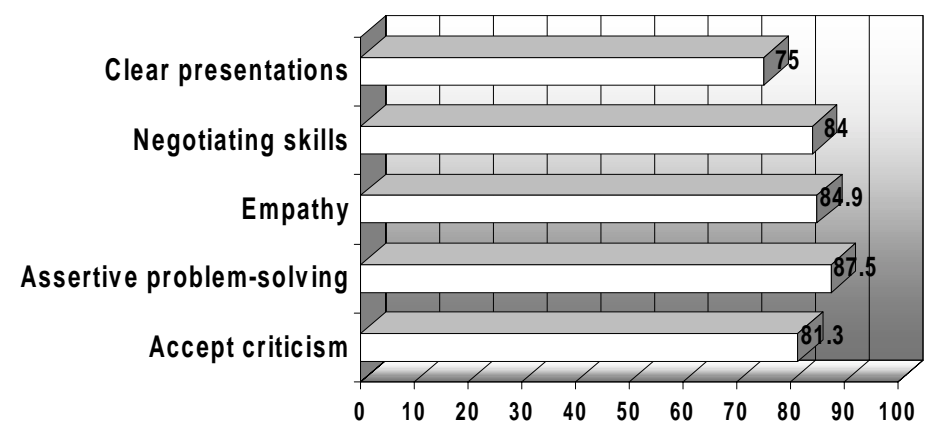

Figure 3: Interpersonal skills of the manager $(\mathrm{N}=112)$

\section{Assertive problem-solving}

Approximately $88 \%$ of respondents indicated assertive problem-solving as a required managerial skill of the supervisor. The problem-solving ability of the supervisor is a key element of the intellectual stimulation leadership approach aimed at stimulating creativity among workers. By involving subordinates in problemsolving situations they have the opportunity to share their own unique ideas and solutions and feel important as a contributor to solving problems in the work situation. The assertiveness element required refers to the fact that the manager should be firm in her decisions. These firm decisions will reassure subordinates of her guiding presence which could enhance motivation in subordinates, and will minimise ethical and medical legal hazards which could easily slip into problem-solving situations where guidance and direction is to be given to subordinates at the same time that potentially hazardous decisions need to be made. Managers can use their courage to be assertive, saying what they believe, and being clear about what they want, to influence and persuade others (Daft, 1999:476).

\section{Negotiation}

Negotiation was indicated by $88 \%$ respondents as a required managerial skill of the supervisor. Negotiation skills comprise a set of learned and acquired skills, which include the use of rules coupled with an imaginative personality (Booyens, 1998:543). During negotiations, each party's self-respect should be protected. This implies that conflicting issues have to be dealt with, not the personalities of individuals. The nurse manager should manage conflict and negotiations constructively in order for an organisation to prosper and to produce work of a high quality (Booyens, 1998:547). 
By solving problems and conflicts effectively the existence and importance of staff members are acknowledged and personnel should consequently feel more committed and motivated to play their part in obtaining the objectives of the organisation.

\section{Empathy}

This characteristic was indicated by approximately $85 \%$ of respondents as a requirement of the supervisor in her quest to assist in motivating subordinates. Empathy, or the awareness of others' feelings, needs and concerns are a crucial component of emotional intelligence. It involves understanding others in an attempt to develop others towards having a service-orientation and possessing a keen political awareness (Rozell, Pettijohn \& Parker, 2002:274). Orientation in this instance equates with motivation.

\section{Acceptance of criticism}

The acceptance of criticism as a required skill of the supervisor in motivating subordinates was indicated by $81 \%$ of the respondents. Usually, people with strong self-awareness accept criticism more readily than people with a weaker self-awareness and self-image. The manager who is open to criticism from other people will be able to develop and manage her own life more easily. Self-awareness means knowing oneself, recognising one's identity, one's strengths and weaknesses and feeling good about oneself (Moller \& Powell, 2001:342). This again contributes positively towards creating an integrated motivational milieu in the working environment.

\section{Clear presentations}

This skill received the least number of responses (75\%). Nonetheless, the agreement is still significant.

Supervisors should have good communication skills and provide subordinates with the relevant information that clearly spells out what is expected of them. Supervisors, who use inspirational motivation as leadership behaviour, set high standards and communicate their ideas and vision to their subordinates in unambiguous ways (Sarros \& Santora, 2001:388). A shared vision is of fundamental importance to the motivation of employees and serves as both an inspiration and a sense of what needs to be done (Hodgkinson, 2002:9091). A supervisor should encourage openness of com- munication, including the frank expression of opinions about work processes and about him/herself as leader (Mullins, Linehan \& Walsh, 2001:119).

In contrast to the above agreements on the role of the supervisor in motivating the self and subordinates, significant differences in opinion were found in an item regarding risk management.

\section{Risk management}

In this instance, approximately half $(50 \%)$ of the respondents (Figure 4) did not agree on the statement that they should not take chances as their safety was more important than the situation. Half of the respondents felt that risk taking in management practices had a pertinent role in their current working situation with their direct supervisor $\left(X^{2}=6,54, p<0,01\right)$.

\section{Motivational concept:}

Recognition

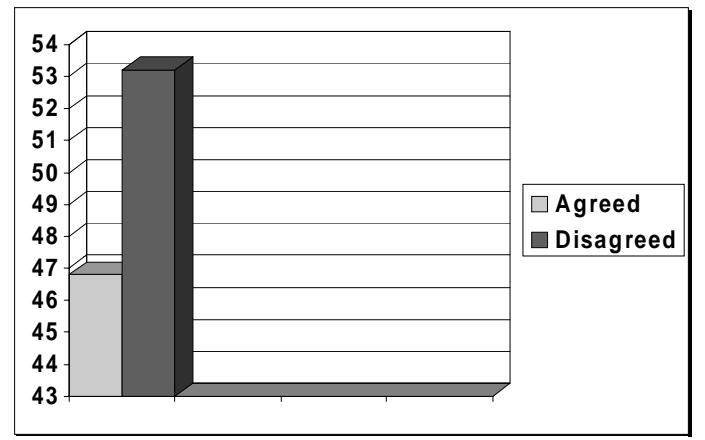

Figure 4: Significant differences between respondents on risk management $(\mathrm{N}=112)$

A higher percentage of functional level nurses $(61,0 \%)$ than top-level nurses $(34,4 \%)$ agreed that they should not take chances in their current working situation (Figure 5). This might indicate that senior nurses are more experienced and empowered in making more risky decisions and that they view their safety as less important than their subordinates do $\left(X^{2}=6,45, p<0,01\right)$.

A study on the relationships between perceptions of supervisor power and subordinate work attitudes showed that perceived legitimate power and reward power were important predictors of employee motivation (Elangovan, 2000:319). It is important to note that the use of different types of power could have either a positive or a negative impact on the motivation of staff members. 


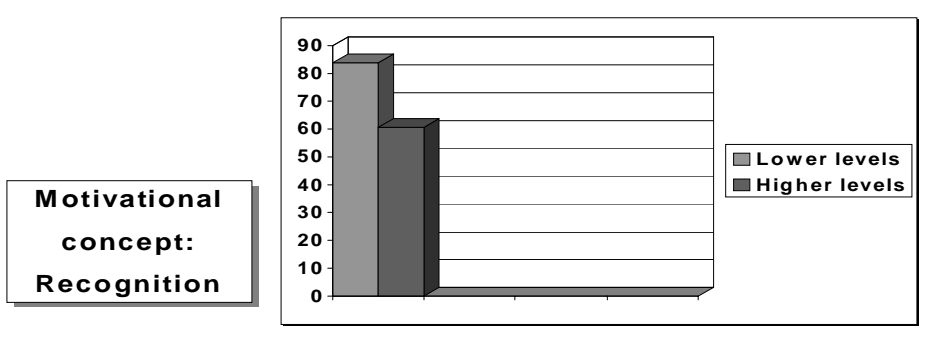

Figure 5: Significant differences between hierarchical levels on risk management $(\mathrm{N}=112)$

\section{Elements of the self-concept of nurses that contributes to motivation}

From the present research findings, it appears that the nature and quality of one's self-concept are foundational in determining the role one takes in self-motivation.

Self-motivation is one of the critical pillars of emotional intelligence. Achievement, drive, commitment, optimism and initiative are key elements in one's self-regulation and these elements determine motivation and performance outcomes (Rozell, Pettijohn \& Parker, 2002:274). With regard to these and other elements of self-concept, some related items from the questionnaire that was used during this study are briefly discussed. Respondents agreed that the following were true about their self-concept with regard to motivation. The level of agreement is given in brackets next to each item (also see table 1).

- I think I am a skilled person (95\%)

Skilfulness contributes towards meaningfulness in the work situation, which is closely linked with motivation (Powell, 2002:57). When a nurse has a good self-esteem regarding her competencies in her work, she is able to face new challenges and express herself by putting new ideas forward to co-workers.

- I have a good sense of humour (94\%)

Struggling with everyday dreariness and suffering in the work environment necessitates a balanced amount of seriousness and humour. Humour allays tension in an excellent positive way and serves as an important motivational force for a person working in a stressful and fast paced working environment. To have a good
Table 1:The self-concept $(\mathrm{N}=112)$

\begin{tabular}{|l|l|}
\hline I think I am a skilled person & $95,3 \%$ \\
\hline I have a good sense of humour & $93,8 \%$ \\
\hline I am someone who people can like & $93,8 \%$ \\
\hline I make a good impression on people & $92,8 \%$ \\
\hline My friends find me interesting & $90,2 \%$ \\
\hline I am quite a pleasant person & $90,1 \%$ \\
\hline I am attractive & $66,1 \%$ \\
\hline
\end{tabular}

sense of humour is essential in balancing conflict and stress at work and in building the self-esteem. Through people's mindsets (beliefs, attitudes, norms) they may arrange their life and work situation to keep the defence mechanisms in place and avoid things that cause them conflict or anxiety (Smith, 2000:44).

- I am someone whom people can like (94\%)

The nurse practitioner should identify and analyse her own desires and expectations, based on her personal preferences. She should evaluate her strengths and weaknesses and should plan her career accordingly (Muller, 1996:357). Knowing one's strengths and weaknesses could motivate one better towards climbing the career ladder.

\section{- I make a good impression on people (93\%)}

Nurses receive frequent feedback from supervisors in the form of performance appraisals. Receiving positive feedback on one's performance is an indicator that one is highly valued by the manager. All human beings respond positive to constructive appraisals and positive behaviour and self-esteem will hereby be enforced. Competence in one's field of practice could lead to exercising expert power in the work environment. The latter is a great motivational force especially when colleagues approach one for advice and assistance in handling of problems and making decisions. A person earns the trust of colleagues by being who you are, by being real. A health professional should inspire loyalty, trust and confidence. Where there is trust, others can come to see you in the same light. People will want to work with you and give you the best (Smith, 2000:170).

- My colleagues find me interesting (90\%)

For colleagues to find one interesting is a compliment and a motivator. It makes one feel worthwhile and motivated to proceed with positive behaviour towards them. Being able to express one's personality at work is a 
key motivator (Powell, 2002:58). Keeping the "worthits" in mind help nurses to stay motivated and on track in the work situation. A nurse who experiences a positive interpersonal relationship with her co-workers also experiences positive thoughts about herself. The following two statements have bearing in this regard too:

- I am quite a pleasant person (90\%)

- I am attractive/handsome (66\%)

Significant differences between top and lower level nurses were also identified in two items regarding the self-concept. More functional level nurses $(98,7 \%)$ than top-level nurses $(84,9 \%)$ indicated that they thought they made a good impression on people $\left(X^{2}=8,47, p\right.$ $<0,01)$. The same tendency was found where approximately 99 percent functional level nurses, as compared to 91 percent top level nurses, thought that they were someone whom people like $\left(X^{2}=3,87, p<0,05\right)$.

These findings indicate that lower level nurses might have a better self-concept than their superiors. Still, all managers have the responsibility to develop their own and subordinate's skills for self-development and selfesteem.

\section{GUIDELINES FOR FUTURE MOTIVATION OF NURSES}

\section{Guidelines for the manager as direct su- pervisor in motivating nurses}

The following guidelines (Figure 6) were identified as important for the effective motivation of subordinates by supervisors. Supervisors should themselves be motivated. They should:

- be able to present positive and clear discussions on a wide array of topics including, for instance, changes in policy;

- use negotiation skills to promote and acknowledge the good work being done by subordinates through, for instance, merit ratings;

- show empathy towards subordinates by assisting them in developing strategies to improve working conditions;

- use assertive problem-solving skills in enrichment of the daily task design and therefore promotes the interaction among subordinates;

- accept criticism by changing her negative behaviour and by correcting her mistakes; and

- realise the potential of every employee whereby teamwork should be encouraged.

With regard to the latter, Koch (1995:32) also emphasises excellence in teamwork and the establishment of cross-functional quality improvement teams as two factors, which are essential to the role of the direct supervisor in motivating staff. The value of teamwork and the synergy it generates is well documented.

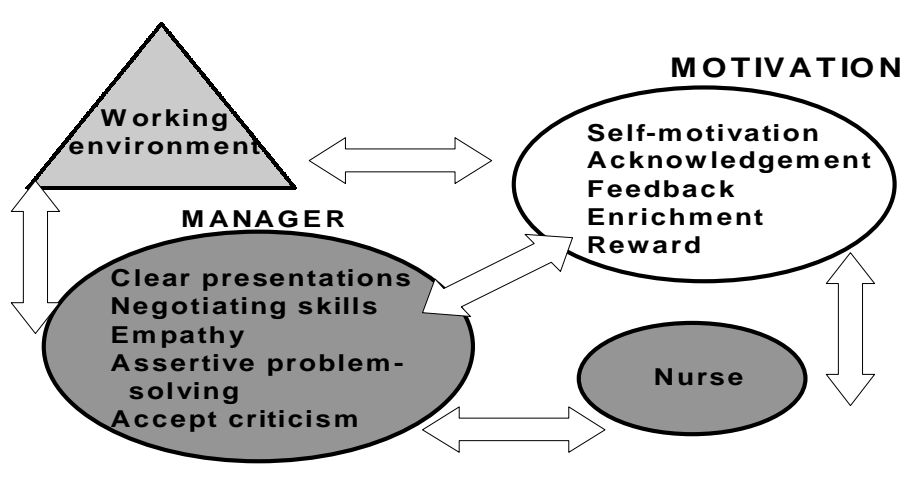

Figure 6: The role of the manager in motivating nurses

It is also believed that when you encourage your staff to focus on the "worth-its" of their goals, you help motivate them in a most basic way. The role of the top manager in a transforming health organisation is an extremely challenging one. Developing a vision, motivating a workforce, building commitment to these and communicating these constantly, are key responsibilities of a top manager. The need to empower stakeholders within and outside the organisation to support any change required to attain the vision of the organisation and to stay motivated, requires top managers who can connect with a wide range of people and who can build partnerships that will secure organisational success. A passion for understanding human intervention, behaviour and motivators is needed to encourage and drive teams and individuals to own and commit to change. This also requires leaders who have imagination, creativity and self-motivation (Hackett \& Spurgeon, 1998:170-177) - self-motivation that could flow over to motivate others. 


\section{Guidelines for self-motivation for the in- dividual nurse and supervisor}

From the findings regarding the self-concept the following conclusions/guidelines were formulated for all levels of nurses/managers to improve self-motivation (Figure 7). These individuals should become self-motivated by:

- feeling good about themselves and making a good impression;

- experiencing a sense of humour to enrich their daily task;

- acknowledging the role of motivation in job satisfaction;

- being pleasant;

- experiencing individual rewards;

- focussing on positive wording in feedback and in positive self-talk.

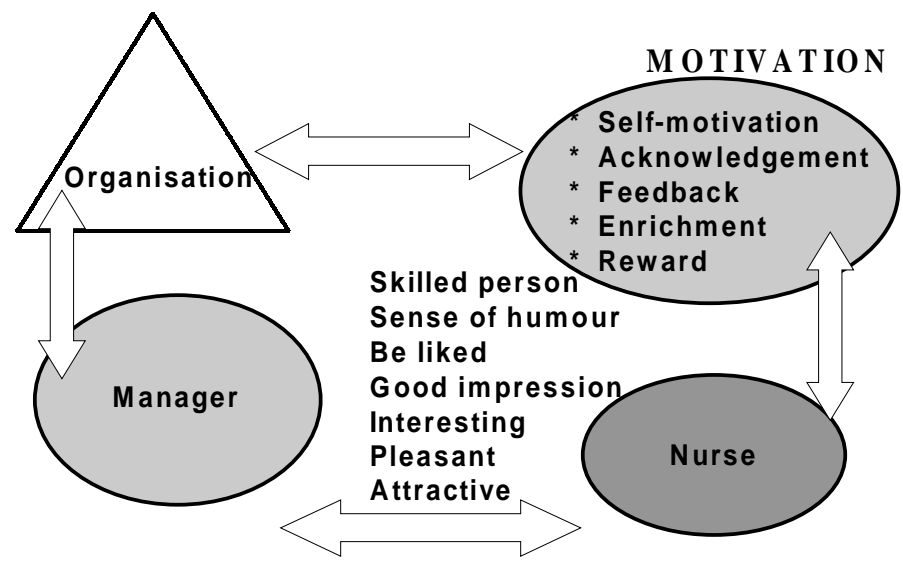

Figure 7: The role of the self-concept in motivation

Self-motivation leads to satisfaction with what one does which in turn enables one to progress. This necessitates that motivation comes from within the individual. Though someone else may be able to inspire another, they cannot motivate someone else (Moller \& Powell, 2001:342).

The following ten suggestions could assist in improving one's self-image whereby self-motivation can be improved as well -

- Stop all negative talk.

- Do not compare yourself to others.

- Do not run yourself down.
- Realise you are more capable than you think you are.

- Do not listen to negative people and drop negative words from your own vocabulary.

- See the good points in others.

- Give yourself credit.

- Stop needing approval.

- Forget the past.

- Know that you can if you believe you can.

\section{CONCLUSION}

Nurses have to become aware on the importance of being actively involved in the attainment of their personal objectives. Involvement through internal motivation is and has been the power behind mankind's success and achievements. Managers should create a milieu to which subordinates would want to belong namely a motivational milieu (Figure 8). The latter can be achieved through a new management style in which manager's approach subordinates as being:

- intelligent, trustworthy and motivated;

- the most critical and valuable strategic asset a health care organisation has; and

- the fundamental resource on which the success of the health organisation is founded.

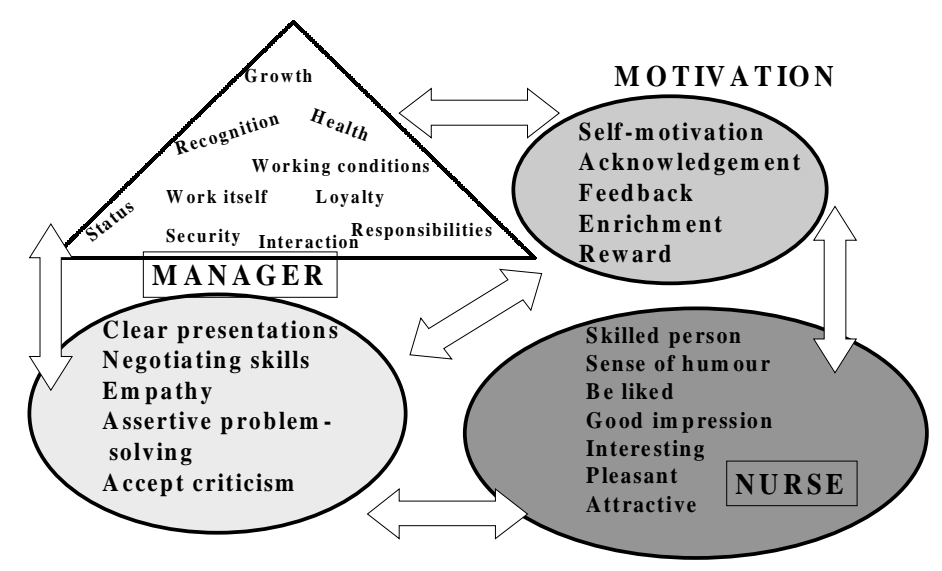

Figure 8:The motivational process

\section{BIBLIOGRAPHY}

ANALOUI, F 2000: What motivates managers? Journal of Managerial Psychology, 15(4):324-340.

BABBIE, E \& MOUTON, J 2001: The practice of social research; South African edition. Cape Town: Oxford.

BLESS, C \& HIGSON-SMITH, C 1995: Fundamentals of social 
research methods. An African perspective; $2^{\text {nd }}$ edition. Cape Town: Juta.

BOOYENS, SW 1998: Dimensions of nursing management; $2^{\text {nd }}$ edition. Cape Town: Juta.

BYHAM, WC 1992: Would you recognise an empowered organisation if you saw one? Tapping the Network Journal, 3(2):10-13.

CUNNINGHAM, I \& HYMAN, J 1996: Empowerment: the right medicine for improving commitment and morale in the NHS? Health Manpower Management, 22(6):14-24.

DAFT, RL 1999: Leadership. Theory and practice. London: Harcourt College.

ELANGOVAN, AR 2000: Effects of perceived power of supervisor on subordinate work attitudes. The Leadership \& Organisational Development Journal, 21(6):319-328.

GUY, RF; EDGLY, CE; ARAFAT, I \& ALLEN, DE 1987: Social research methods: puzzles and solutions. Boston: Allyn \& Bacon.

HACKETT, M \& SPURGEON, P 1998: Developing our leaders in the future. Health Manpower Management, 24(5):170-177. HODGKINSON, M 2002: A shared strategic vision: dream or reality? The Learning Organisation, 9(2):89-95.

KINLAW, DC 1995: The practice of empowerment. Making the most of human competence. England: Gower.

$\mathrm{KOCH}, \mathrm{HCH}$ 1995: Motivating staff through teamwork: process review and data display. Health Manpower Management, 21(4):32-36.

KRAMER, M \& SCHMALENBERG, C 1993: Learning from success: autonomy and empowerment. Nursing Management, 24(5):58-59, 62, 64.

MDONGO, L 1995: Empowering employees: creating energy for continuous improvement. Human Resource Management, 11(2):14, 16.

MOLLER, C \& POWELL, S 2001: Emotional intelligence and the challenges of quality management today. Leadership and Organisational Development Journal, 22(7):341-345.

MULDER, JC 1989: Statistiese tegnieke in Opvoedkunde. Pretoria: HAUM.

MULLER, ME 2002: Nursing dynamics; 3rd edition. Johannesburg: Heinemann.

MULLINS, J; LINEHAN, M \& WALSH, JS 2001: People-centred management policies: a new approach in the Irish public service. Journal of European Industrial Training, 25(2/3/4):116-125. POLIT, DF \& HUNGLER, BP 1993: Nursing research. Methods, appraisal and utilisation; $3^{\text {rd }}$ edition. Philadelphia: Lippincott.

POWELL, L 2002: Shedding a tier: flattening organisational structures and employee empowerment. International Journal of Educational Management, 16(1):54-59.

ROZELL, EJ; PETTIJOHN, CE \& PARKER, RS 2002: An empirical evaluation of emotional intelligence. Journal of Management
Development, 21(4):272-289.

SARROS, JC \& SANTORA, JC 2001: The transformational-transactional leadership model in practice. Leadership and Organisation Development Journal, 22(8):383-394.

SMITH, S 2000: Inner leadership. London: Nicholas Brealey. VOGT, JF \& MURRELL, KL 1990: Empowerment in organisations. How to spark exceptional performances. Santiago: Pfeiffer. 